\title{
Witold Gieszczyński
}

\section{OBCHODY 70. ROCZNICY URODZIN JÓZEFA STALINA W GRUDNIU 1949 ROKU (NA PRZYKŁADZIE WOJEWÓDZTWA OLSZTYŃSKIEGO)}

Słowa kluczowe:

Schlüsselwörter:

Keywords:
Józef Stalin, 70. rocznica urodzin, 1949 rok, województwo olsztyńskie Josef Stalin, Stalin 70. Geburstag, 1949 Jahr, Woiwodschaft Olsztyn

Joseph Stalin, $70^{\text {th }}$ anniversary of the birth of Joseph Stalin, 1949 year, Olsztyn Voivodeship

Prometeusz nowej ery, Największy Geniusz Wszystkich Czasów, Słońce Narodów, Koryfeusz Nauki, Górski Orzeł - to tylko niektóre z licznych określeń Józefa Stalina w okresie szczytu kultu sowieckiego dyktatora. Józef Stalin, a właściwie Iosif Dżugaszwili urodził się 6(18) grudnia 1878 roku w gruzińskim Gori, jako syn szewca Wissariona Dżugaszwili i praczki Ketewan Geladze ${ }^{1}$. Jednak według oficjalnej wersji obowiązującej przez lata w Związku Sowieckim Stalin miał się urodzić 9(21) grudnia 1879 roku i właśnie tego dnia obchodzono rocznicowe uroczystości². Początki kultu Stalina sięgają roku 1929, kiedy oficjalnie przypadała pięćdziesiąta rocznica jego urodzin, natomiast po drugiej wojnie światowej osiągnął swój szczyt ${ }^{3}$. Ponieważ Stalin był wszechwładny, wszechobecny, wszechwiedzący i nieomylny, toteż zarówno w Związku Sowieckim, jak i w państwach satelickich Moskwy oddawano mu nieomal boską cześć ${ }^{4}$ Szczególnie było to widoczne pod-

1 Szerzej na ten temat zob. E. Radziński, Stalin, Warszawa 1996, s. 26; E. Duraczyński, Stalin: twórca i dyktator supermocarstwa, Pułtusk - Warszawa 2012, s. 14; S.S. Montefiore, Stalin: dwór czerwonego cara, Warszawa 2015, s. 23; O. Khlevniuk, Stalin: nowa biografia, Kraków 2016, ss. 29-30.

2 Газета „Правда” № 355 от 21 декабя 1949 года, c.1-12; Wielki wódz i nauczyciel Komunistycznej Partii i Narodu Radzieckiego. Na siedemdziesięciolecie urodzin J. W. Stalina, Wydział Propagandy i Agitacji przy CK WKP(b) oraz Instytut Marksa - Engelsa - Lenina przy CK WKP(b), Warszawa 1949, s. 3; Józef Stalin. Krótki życiorys, oprac. J. Aleksandrow, M. Gałaktionow, W. Krużkow, M. Mitin, W. Moczałow, P. Pospiełow, Warszawa 1953, s. 5; Большая Советская Енциклопедия, (ред.) А. М. Прохоров, т. 24, Москва 1976, с. 400-401.

3 Zob. J. Smaga, Narodziny i upadek imperium. ZSRR 1917-1991, Kraków 1992, s. 122, 193; D.R. Marples, Historia ZSRR. Od rewolucji do rozpadu, Wrocław - Warszawa - Kraków 2006, s. 203; J. Plamper, Kult Stalina. Studium alchemii władzy, Warszawa 2014, s. 17.

4 Zob. R. Pipes, Komunizm, Warszawa 2008, ss. 84-85. 
czas uroczystości związanych z siedemdziesiątą rocznicą urodzin generalissimusa w 1949 roku obchodzonych $\mathrm{z}$ iście bizantyjskim przepychem i rozmachem ${ }^{5}$. Jednak popadający w coraz większą paranoję, starzejący się i schorowany dyktator obawiając się zamachu na swoje życie coraz częściej korzystał z usług sobowtóra ${ }^{6}$. Mimo to postanowiono hucznie świętować siedemdziesiąte urodziny „Ojca narodów”. Z tej okazji uruchomiono ogromną machinę propagandową zarówno w samym Związku Sowieckim, jak i w tzw. w krajach satelickich, w tym także w Polsce.

Jubileusz siedemdziesięciolecia urodzin Stalina przypadał w czasie postępującej sowietyzacji kraju. Należy przypomnieć, że we wrześniu 1947 roku w Szklarskiej Porębie odbyła się narada liderów dziewięciu europejskich partii komunistycznych i robotniczych, podczas której podjęto decyzję o utworzeniu Komunistycznego Biura Informacyjnego (Kominform $)^{7}$. W praktyce oznaczało nową instytucjonalną formę kontroli przez Kreml nad partiami komunistycznymi szczególnie w państwach Europy Środkowo-Wschodniej, a w praktyce służyło jeszcze ściślejszemu uzáleżnieniu ich od Związku Sowieckiego. Stálinowska koncepcja sowietyzacji zakładała niepodzielne rządy partii komunistycznej, jaką była Polska Zjednoczona Partia Robotnicza, bezwzględne zwalczanie i likwidację przeciwników politycznych, terror komunistycznego aparatu bezpieczeństwa, polityczną indoktrynację społeczeństwa, walkę z Kościołem katolickim, likwidację tzw. klas posiadających, własności prywatnej oraz wolnego rynku, stworzenie gospodarki centralnie sterowanej, nacjonalizację przemysłu, kolektywizację rolnictwa, a także podporządkowanie jednostki kolektywowi, głęboką ingerencję państwa w prywatne życie obywateli, całkowite uzależnienie nauki, kultury i sztuki od ideologii komunistycznej. Jednym z ważniejszych zadań służących zwasalizowaniu Polski było przejęcie przez Sowietów całkowitej kontroli nad wojskiem. Miało temu służyć powołanie 6 listopada 1949 roku na urząd ministra obrony narodowej oraz mianowanie na stopień marszałka Polski Konstantego Rokossowskiego dotychczasowego dowódcy Północnej Grupy Wojsk Armii Sowieckiej'. Choć Rokossowski z pochodzenia był Polakiem, to nad Wisłą faktycznie pełnił rolę sowieckiego namiestnika bez reszty

\footnotetext{
P.P. Wieczorkiewicz, Sowiety. Historia ZSRS, Łomianki 2017, s. 153.

6 M. Heller, A. Niekricz, Utopia u władzy. Historia Zwiazku Sowieckiego. Od potęgi do upadku 19391991, Poznań 2016, s. 292.

Szerzej: W. Borodziej, Od Poczdamu do Szklarskiej Poręby. Polska w stosunkach międzynarodowych 1945-1947, Londyn 1990, ss. 344-345; I. Jażborowska, Utworzenie Kominform. Kominform jako narzędzie manipulacji Stalina w Polsce, Dzieje Najnowsze, 1999, nr 2, ss. 117-135; M. Golon, U źródet ,zimnowojennego" podziału świata - powstanie i działalność Biura Informacyjnego Partii Komunistycznych i Robotniczych (Kominformu) w latach 1947-1950, w: Polska w podzielonym świecie po II wojnie światowej (do 1989 r.), red. M. Wojciechowski, Toruń 2002, ss. 91-126.

8 Szerzej: N. Iwanow, Komunizm po polsku. Historia komunizacji Polski widziana z Kremla, Kraków 2017, ss. 395-416.

9 T. Mołdawa, Ludzie władzy 1944-1991. Władze państwowe i polityczne Polski według stanu na dzień 28 II 1991, Warszawa 1991, s. 100.
} 
oddanemu Stalinowi ${ }^{10}$. Wraz z „marszałkiem dwóch narodów” do Polski przeniesiono 271 wyższych oficerów Armii Sowieckiej, którzy najczęściej obejmowali kluczowe stanowiska w Wojsku Polskim ${ }^{11}$.

Przygotowania do obchodów siedemdziesięciolecia urodzin sowieckiego dyktatora rozpoczęto na długo przed kulminacją, która miała nastąpić 21 grudnia 1949 roku. Zgodnie z uchwałą Biura Politycznego KC PZPR postanowiono „uczcić 70-lecie urodzin Towarzysza Józefa STALINA przez zaznajomienie całej Partii i klasy robotniczej z życiem i walką wielkiego wodza i nauczyciela międzynarodowego ruchu robotniczego, z Jego wkładem w rozwój nauki marksizmuleninizmu” ${ }^{12}$. Podkreślano też, iż „znajomość dzieła życia i walki Towarzysza Józefa Stalina podniesie poziom ideologiczny Partii i klasy robotniczej, będzie ogromną pomocą w wychowaniu i kształtowaniu działaczy nowego leninowskostalinowskiego typu, nieustraszonych w walce o Polskę socjalistyczną, nierozerwalnie związanych z ludem, nieubłaganych wobec wrogów ludu"13. Ponadto KC PZPR wydał specjalną instrukcję, będącą swoistym scenariuszem dla „odpowiedniego" przebiegu uroczystości jubileuszowych w całym kraju, której zapisów miano ściśle przestrzegać ${ }^{14}$.W dokumencie tym określano sposób organizowania, ,specjalnych zebran organizacji podstawowych", na których miały być wygłoszone referaty na temat ,zycia i dzieła tow. Stalina”. Ponadto w całym kraju zdecydowano o zainicjowaniu zobowiązań produkcyjnych zarówno załóg pracowniczych, ale także poszczególnych oddziałów, brygad i pracowników. We współzawodnictwie pracy miała też uczestniczyć młodzież skupiona w zakładach pracy, szkołach oraz organizacjach młodzieżowych, przede wszystkim Związku Młodzieży Polskiej czy też Powszechnej Organizacji „Służba Polsce”. Ponadto w ramach szkolenia ideologicznego polecono tworzenie kólek samokształceniowych celem studiowania życiorysu Stalina. W tym celu zalecano przygotowanie okolicznościowych wystaw książek i gazetek ściennych. We wspomnianej instrukcji wskazywano też na konieczność zorganizowania i pokierowania „oddolną inicjatywą” zakładów pracy, robotników, kobiet, młodzieży szkolnej, a także dzieci - „masowego wysyłania listów z życzeniami do tow. Stalina”. Wytyczne KC PZPR dotyczyły również przebiegu akademii zarówno na szczeblu wojewódzkim, jak i powiatowym, które - jak podkreślano winny mieć „charakter uroczysty”, natomiast 21 grudnia 1949 roku, a więc w dniu

10 N. Pietrow, Nowy ład Stalina. Sowietyzacja Europy 1945-1953, Warszawa 2015, s. 178; P.P. Wieczorkiewicz, op. cit., s. 173.

11 Zob. E.J. Nalepa, Oddani partii Lenina i Stalina. Czerwonoarmiści w Wojsku Polskim 1943-1968, Piotrków Trybunalski 2017, s. 105.

12 „Nowe Drogi”. Czasopismo społeczno-polityczne. Organ KC PZPR 1949, nr 5(17), ss. 3-4; „Trybuna Ludu" (dalej: TL) 1949, nr 292 z 24 X, s.1.

13 Ibidem.

14 Szerzej na ten temat zob. R. Kupiecki, „Natchnienie milionów”. Kult Józefa Stalina w Polsce 1944-1956, Warszawa 1993, ss. 84-85. 
oficjalnych urodzin polecono „udekorować gmachy partyjne i publiczne barwami polskimi i radzieckimi, portretami tow. Stalina i hasłami”.

Podjęto także decyzję o powołaniu Komitetu Obchodu 70-lecia urodzin Józefa Stalina „niezłomnego szermierza wieczystej przyjaźni narodów ZSRR i Polski, chorążego światowego obozu obrońców pokoju, wolności i niepodległości”15. W tej sytuacji zarówno na szczeblu centralnym, jak i wojewódzkim tworzono takie komitety. I tak na czele Ogólnokrajowego Komitetu stanął przewodniczący KC PZPR oraz prezydent RP Bolesław Bierut, natomiast w jego składzie znaleźli się m.in. marszałek Sejmu Władysław Kowalski, premier Józef Cyrankiewicz, marszałek Polski Michał Żymierski, członkowie rządu, przedstawiciele partii i stronnictw politycznych, Związku Bojowników o Wolność i Demokrację, Towarzystwa Przyjaźni Polsko-Radzieckiej, Związku Samopomocy Chłopskiej, Ligi Kobiet, a także przodownicy pracy, przedstawiciele wojska, związków zawodowych, organizacji społecznych, srodowisk naukowych, twórczych i artystycznych ${ }^{16}$. Według podobnego klucza w całym kraju rekrutowano też cźłonków komitetów wojewódzkich.

W liczącym trzydzieści osiem osób Wojewódzkim Komitecie obchodów 70-lecia Stalina w Olsztynie znaleźli się m.in. I sekretarz KW PZPR Paweł Wojas (przewodniczący), wojewoda gen. Mieczysław Moczar, II sekretarz KW PZPR Bronisław Jachimowicz, przewodniczący Olsztyńskiej Wojewódzkiej Rady Narodowej Stanisław Piaskowski, przewodniczący Okręgowej Rady Związków Zawodowych Aleksander Bartnikowski, prezes Wojewódzkiego Zarządu Zjednoczonego Stronnictwa Ludowego Józef Pawłowski, prezes Komitetu Wojewódzkiego Stronnictwa Demokratycznego Kazimierz Lisowski, prezes Wojewódzkiego Komitetu Stronnictwa Pracy Józef Szyrmer, szef Wojewódzkiego Urzędu Bezpieczeństwa Publicznego płk Antoni Punda, komendant wojewódzki Milicji Obywatelskiej ppłk Aleksander Suchanek, dowódca 15. Dywizji Piechoty Wojska Polskiego płk Józef Kamiński, a także kierownicy wydziałów KW PZPR Janina Juzoń, Kazimierz Szewczyk, Wiktoria Nowicka, Józef Krajewski, Stanisław Lange, II sekretarz KM PZPR Stefan Ćwiek, dyrektor Teatru im. Stefana Jaracza Władysław Surzyński ${ }^{17}$.

Pierwsze uroczystości odbyły się już kilka tygodni przed dniem 70. rocznicy urodzin Stalina. Zaczęto wówczas organizować różnego rodzaju wiece, zebrania, akademie i masówki. Toteż 6 października 1949 roku na placu Armii Czerwonej ${ }^{18}$ w Olsztynie odbył się uroczysty pochód inaugurujący „Miesiąc Pogłębienia Przyjaźni Polsko-Radzieckiej”. W uroczystości oprócz przedstawicieli władz politycznych wzięły udział kompanie wojska i straży pożarnej, a także delegacje 164 kół

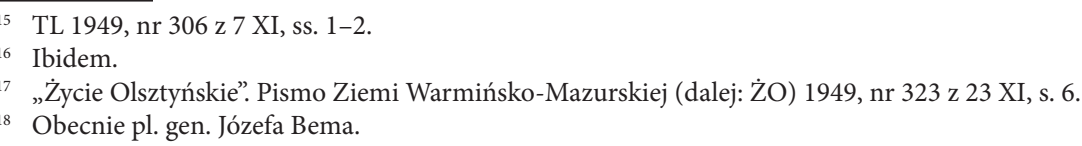


TPPR z Olsztyna oraz młodzież szkolna ${ }^{19}$. W czasie pochodu, który przemaszerował ulicami Zwycięstwa ${ }^{20}$, Stalina ${ }^{21}$, Partyzantów, 1 Maja i 22 Lipca $^{22}$ na plac gen. Świerczewskiego ${ }^{23}$ „wznoszono liczne okrzyki na cześć Generalissimusa Stalina, Związku Radzieckiego i Armii Czerwonej" ${ }^{24}$. Im było bliżej końca roku podobnych uroczystości organizowano znacznie więcej. Podczas dwudniowej odprawy sekretarzy komitetów gminnych wojewódzkiej organizacji partyjnej, która odbyła się w Olsztynie w dniach 9-10 grudnia 1949 r., w ramach szkolenia ideologicznego jej uczestnicy wysłuchali referatu Stanisławy Aleksandrowicz z KW PZPR na temat życia i działalności Józefa Stalina ${ }^{25}$. Z kolei 14 grudnia 1949 roku na placu gen. Świerczewskiego odbył wiec poparcia z okazji siedemdziesiątej rocznicy urodzin Stalina. Według oficjalnych relacji, uczestniczyło w nim ok. 8 tys. osób. Okolicznościowe przemówienie wygłosił Stefan Ćwiek II sekretarz KM PZPR w Olsztynie ${ }^{26}$. Coraz obfitszym strumieniem napływały także wszelkiego rodzaju życzenia, zobowiązania oraz deklaracje związane z jubileuszem ${ }^{27}$. Już 6 grudnia 1949 roku podczas zebrania koła TPPR działającego przy Wojewódzkiej Szkole Partyjnej PZPR w Olsztynie "z okazji nadchodzącej rocznicy dla uczczenia 70-lecia urodzin Generalissimusa Stalina" postanowiono wysłać do Moskwy życzenia urodzinowe ${ }^{28}$ Z kolei, jak donosiła miejscowa prasa, na ręce Zarządu Wojewódzkiego Ligi Kobiet w Olsztynie z poszczególnych powiatów województwa napływały życzenia od „kobiet wiejskich" z PGR-ów, spółdzielni produkcyjnych i kół gospodyń wiejskich ${ }^{29}$. Podkreślano przy tym, że „życzenia długich lat życia i przewodnictwa narodom miłującym pokój wydrukowane są na ozdobnych laurkach, starannie wykonanych przez wiejski aktyw kobiecy" ${ }^{30}$. Także kobiety z Górowa Iławeckiego składały podobne życzenia wraz z zapewnieniem, że „wytężą wszystkie siły w pracy, aby na

19 Jak oficjalnie informowano pod koniec „Miesiąca Pogłębienia Przyjaźni Polsko-Radzieckiej” liczba członków TPPR miała wzrosnąć o 12021 osób, zatem liczba wszystkich członków TPPR w województwie olsztyńskim wynosiła wówczas 60 588. Jak podkreślano, wzrost ten był „wyrazem stale pogłębiających się w narodzie polskim uczuć przyjaźni dla kraju zwycięskiego socjalizmu”. Zob. TL 1949, nr 305 z 6 XI, s. 5.

20 Obecnie al. Marszałka Józefa Piłsudskiego.

21 Obecnie ul. Dąbrowszczaków.

22 Obecnie ul. 11 Listopada.

23 Obecnie Targ Rybny.

24 TL 1949, nr 276 z 8 X, s. 7.

25 Archiwum Państwowe w Olsztynie (dalej: APO), Komitet Wojewódzki Polskiej Zjednoczonej Partii Robotniczej w Olsztynie (dalej: KW PZPR), sygn. 1141/1221. Komunikat KW PZPR w Olsztynie z 14 XII 1949 r.

26 APO, KW PZPR, sygn. 1141/1221. Komunikat KW PZPR w Olsztynie do KC PZPR z 16 XII 1949 r.; TL 1949, nr 345 z 16 XII, s. 7.

27 APO, Prezydium Miejskiej Rady Narodowej w Olsztynie (dalej: PMRN), 458/1. Sprawozdanie z plenarnego posiedzenia MRN w Olsztynie z 8 XII 1949 r.

28 APO, KW PZPR, 1141/2713. Protokół nr 2 zebrania koła TPPR przy Wojewódzkiej Szkole Partyjnej PZPR w Olsztynie z 6 XII 1949 r.

29 ŻO 1949, nr 337 z 7 XII, s. 6.

30 Ibidem. 
całym świecie zapanowało szczęście i socjalizm"31. Z kolei kobiety z Ostródy wyrażały generalissimusowi Stalinowi „wdzięczność za pomoc w odzyskaniu wolności, za zapewnienie bezpieczeństwa i nienaruszalności naszych granic na Odrze i Nysie", natomiast aktywistki Ligi Kobiet w Pasłęku obok urodzinowych życzeń złożyły także obietnicę, że „wychowywać będą swe dzieci w duchu pokoju i bratniej współpracy narodów"32. Życzenia o podobnej treści nadsyłały także koła Ligi Kobiet z innych miejscowości województwa olsztyńskiego.

Podczas plenarnego posiedzenia Miejskiej Rady Narodowej, które odbyło się 19 grudnia 1949 roku w Olsztynie przewodniczący Aleksander Kruczyński wygłosił referat o życiu i działalności Józefa Stalina ${ }^{33}$. Członkowie klubu radnych PZPR złożyli „deklarację i zobowiązanie, w przededniu 70-ciolecia urodzin tow. Generalissimusa Stalina, Wielkiego Nauczyciela i Budowniczego Państwa Socjalistycznego, Niestrudzonego Bojownika o wolność i szczęśliwość ludzi pracy na całym świecie, Opokę Pokoju i Wielkiego Przyjaciela Polski, że trwale i nieustępliwie będą dążyć do kierowania się w pracy ideologią marksistowsko-leninowskąa". Zobowiązano się też „do osiągnięcia lepszych wyników pracy, by u progu rozpoczęcia planu 6-cioletniego rozbudowy Polski Ludowej w drodze do socjalizmu, przyczynić się do przybliżenia tego czasu szczęśliwości ludzkiej”34.

Z-kolei Jan Trzópek, w imieniu aktywu Miejskiego Komitetu Wykonawczego ZSL przyrzekał, iż „pogłębi pracę nad zbliżeniem wsi do miasta, wyrównaniem różnic oraz będzie dążył do podniesienia formy gospodarki rolnej przez uspółdzielczenie wsi i tym samym zapewnienie dostatecznej ilości surowców dla przemysłu i produktów żywnościowych dla miast i okolic przemysłowych". Poza tym radny Trzópek podkreślił, że przez „wzmożenie pracy nad uspółdzielczeniem wsi [...] można skrócić czas socjalizacji kraju”. Równocześnie zobowiązał się, że aktyw olsztyńskiego ZSL „dołoży maksimum wysiłku nad realizacją planu sześcioletniego" ${ }^{35}$. W imieniu klubu radnych Stronnictwa Demokratycznego przemawiał Eugeniusz Szpaderski, który podkreślił, iż jego środowisko „solidaryzując się z treścią referatu” przewodniczącego Kruczyńskiego z okazji siedemdziesiątej rocznicy urodzin „Wielkiego Stalina, Genialnego Wodza zwycięskich armii radzieckich, Pogromcy faszyzmu, Oswobodziciela Naszej Ojczyzny, Niezłomnego w walce o pokój i powszechną sprawiedliwość, Nauczyciela i Wychowawcy przodujących narodów demokratycznych świata” ślubował „wzmóc wysiłki i energię na powierzonym sobie odcinku pracy w MRN celem uczczenia czynem tej doniosłej, historycznej uroczystości i wyrażenia w ten sposób swych uczuć i miłości dla Wielkiego Do-

31 Ibidem.

32 Ibidem.

33 Zob. Kronika Olsztyna 1945-1950. Zapisał i wydał A. Wakar, Olsztyn 1972, s. 146.

34 APO, PMRN, sygn. 458/1. Protokół nr 15/49.

35 Ibidem. 
broczyńcy ludzkości”36. Następnie, w imieniu olsztyńskiego ZBoWiD, przemawiał Kazimierz Mazurkiewicz. Złożył oświadczenie, w którym m.in. podkreślił, iż „obowiązkiem naczelnym członka Związku jest walka o święte prawo narodów do wolności, do przebudowy społecznej, walka o trwały pokój” dlatego - jak podkreślił - „W walce tej pod przewodnictwem potężnego Związku Radzieckiego i Wodza Sił Postępu i Pokoju Generalissimusa Stalina nie ustaniemy, póki nie doprowadzimy jej do zwycięskiego końca" ${ }^{37}$. Kolejne deklaracje złożyli, w imieniu ZMP radny Janusz Sołtykiewicz, natomiast w imieniu Towarzystwa Przyjaźni Polsko-Radzieckiej Eugeniusz Dołżański, który jako delegat Zarządu Grodzkiego podkreślił, iż TPPR „zobowiązuje się stale pogłębiać przyjaźń między narodem polskim i narodami Związku Radzieckiego stojącego na straży interesów całego świata pracy, usuwanie wyzysku człowieka przez człowieka, budowy na całym świecie ustroju socjalistycznego"si.

Coraz szerzej napływały również meldunki o powziętych zobowiązaniach produkcyjnych. Jednak analizując ich treść nasuwa się nieodparte wrażenie, że były podejmowane ad hoc, jedynie dla zrealizowania określonego celu. Wspomniano np., ze „dla uczczenia 70-letniej Rocznicy Urodzin Generalissimusa Stalina, Międzynarodowego Wodza Postępu i Pokoju robotnicy i pracownicy umysłowi wszystkich przedsiębiorstw komunalnych Olsztyna" złożyli szereg postanowień i zobowiązań. Dla przykładu załoga Przedsiębiorstwa Wodociągów i Kanalizacji informowała o wykonaniu trzy dni przed terminem nowego kanału w podolsztyńskim Kortowie o długości 180 metrów bieżących. Z kolei olsztyńska Gazownia Miejska w dniu urodzin Stalina postanowiła otworzyć zakładową bibliotekę, z której „będzie korzystał świat pracy”. Także załoga Miejskich Zakładów Komunikacyjnych zobowiązała się do końca 1949 roku „wykonać uporządkowanie” dwóch pętli trolejbusowych oraz „oczyścić dwie zajezdnie ze złomu”, natomiast pracownicy rzeźni miejskiej i targowisk zwierzęcych zobowiązali się „wykonać dodatkowo [...] dach betonowy nad odbudowywaną rzeźnią sanitarną". Także pracownicy tartaku przez pięć dni, tj. od 19 do 23 grudnia zobowiązywali się „pracować dobrowolnie po 1 godzinie nadliczbowej”, a „uzyskane zarobki za te nadgodziny przeznaczyć na Pomnik Wdzięczności w Warszawie”. Ponadto pracownicy fizyczni i umysłowi przedsiębiorstw komunalnych zobowiązywali się „rozszerzyć współzawodnictwo pracy i podnieść wydajność pracy”, a także „przestudiować życiorys Generalissimusa Stalina” oraz „wziąć gremialny udział” w uroczystych akademiach i innych uroczystościach związanych z siedemdziesięcioleciem urodzin sekretarza generalnego KC WKP(b). Ponadto wszyscy oni zadeklarowali swoje członkostwo

36 Ibidem.

37 Ibidem.

38 Ibidem. 
w TPPR ${ }^{39}$. Pragnąc wyrazić swą „część i wdzięczność Wodzowi Proletariatu” załoga Państwowego Zakładu Wyrobów Drzewnych nr 10 w Olsztynie zameldowała, że na zebraniu w dniu 17 grudnia 1949 roku „powzięto uchwałę [aby] zwiększyć wydajność pracy w przeddzień urodzin Wodza i zasłużyć na miano robotnika Stalina przez osiągnięcie $132 \%$ normy" ${ }^{20}$. Podkreślano przy tym, że zarówno złożone zobowiązania jak i meldunki od poszczególnych załóg pracowniczych zostały przyjęte „huraganowymi oklaskami”. Toteż zapewne na fali tego entuzjazmu radni klubu PZPR zgłosili wniosek „w sprawie wysłania życzeń z plenarnego posiedzenia MRN dla tow. Józefa Stalina"41. Tego samego dnia Miejska Rada Narodowa w Olsztynie podjęła jeszcze uchwałę, w której zobowiązano się „budować podstawy socjalizmu w Polsce” poprzez „wzmożenie większego niż dotychczas wysiłku w przedmiocie wzmocnienia władzy demokracji ludowej, aktywizując prace Rady, prezydium, komisji i każdego poszczególnego członka Rady”. Deklarowano przy tym „pełny udział Rady w realizacji sześcioletniego planu gospodarczego, wzmożenie walki na odcinku Rady z wrogami demokracji ludowej, wykazanie większej czujności klasowej”, a także „stałe podnoszenie oświaty, kultury i sztuki”. Aby „prawidłowo” wypełnić te zadania postanowiono „uczyć się na doświadczeniach historycznych WKP(b) i wzorować się na pracach rad delegatów robotników i chłopów Związku Radzieckiego" 42 .

W ramach tzw. dni pracy stalinowskiej przystąpiono do wykonywania zobowiązań w zakładach przemysłowych województwa olsztyńskiego. W związku z tym meldowano np., że w Zakładach Przemysłu Sklejek w Piszu wszystkie zespoły wykonały swoje zobowiązania produkcyjne od 131 do 191 proc. Także pracownicy Cegielni Klebark w powiecie olsztyńskim wykonali „40 procent ponad przyjęte zobowiązania”. Z kolei w państwowej Fabryce Wyrobów Drzewnych w Olsztynie miano wykonać 147 proc. normy, natomiast załoga Kaflarni Emilianowo w powiecie ostródzkim w ciągu jednego dnia „załadowała” piec kaflarski, a robotnicy „po przekroczeniu 100\% normy zobowiązali się jeszcze przekroczyć o $80 \%$ w dniu następnym"43. Również pracownicy oddziału Państwowej Żeglugi w Giżycku postanowili do dnia 20 grudnia 1949 roku, tj. na pięć dni przed terminem przeprowadzić kapitalny remont statku pasażerskiego „Kryniczanka”, natomiast do 20 grudnia tr.

39 APO, PMRN, sygn. 458/1. Pismo do Prezydium MRN w Olsztynie z 17 XII 1949 r.

40 APO, PMRN, sygn. 458/1. Zobowiązanie Zakładu Wyrobów Drzewnych nr 10 w Olsztynie z 17 XII 1949 r.

${ }^{41}$ W treści wniosku czytamy: „Do Towarzysza Generalissimusa Józefa Stalina, na ręce ambasadora Związku Radzieckiego w Warszawie. W siedemdziesiąta rocznicę Waszych urodzin, Miejska Rada Narodowa m. Olsztyna śle Wam, drogi Towarzyszu, najserdeczniejsze życzenia zdrowia i długich lat życia dla dobra pokoju oraz zwycięstwa socjalizmu w całym świecie”. Zob. APO, PMRN, sygn. 458/1. Wniosek złożony w imieniu klubu radnych PZPR 19 XII 1949 r.; ibidem, Uchwała nr 140/49 z 19 XII 1949 r.

42 APO, PMRN, sygn. 458/1. Uchwała nr 141/49 MRN w Olsztynie z 19 XII 1949 r.

43 APO, KW PZPR, sygn. 1141/1221. Komunikat KW PZPR w Olsztynie z 21 XII 1949 r. 
załoga pracownicza Centralnych Warsztatów Sprzętu Sportowego w Kętrzynie postanowiła wykonać swój plan miesięczny. Także robotnicy kętrzyńskich warsztatów zobowiązali się „,W soboty, po godzinach pracy, oczyścić i przygotować do stanu używalności boisko sportowe", znajdujące się przy warsztatach ${ }^{44}$. Z kolei pracownicy oddziału Centrali Spółdzielni Pracy w Olsztynie uchwalili rezolucję, w której postanowili przeznaczyć połowę przeciętnego, dziennego wynagrodzenia na zakup ciepłej odzieży dla sierocińca, w którym przebywały „dzieci ofiar ostatniej wojny”

Popularną formą uczczenia siedemdziesiątej rocznicy urodzin Stalina stało się wezwanie do zaciągnięcia 20 grudnia 1949 roku tzw. wart stalinowskich, polegających na zgłaszaniu zobowiązań produkcyjnych, które - jak podkreślano - zakłady województwa olsztyńskiego przyjęły z „entuzjazmem”ł6. Wezwanie miały podjąć załogi 22 zakładów pracy, które złożyły 56 zespołowych zobowiązań produkcyjnych ${ }^{47}$. Wśród zakładów, które postanowiły wzmóc produkcję w tym dniu największe zobowiązania podjęła Fabryka Sklejek w Piszu, której załoga postanowiła wykonać ponad 140 proc. normy, natomiast robotnicy roszarni lnu i konopi w Sępopolu meldowali o zwiększeniu wydajności pracy o 20 proc. ${ }^{48} \mathrm{Z}$ innych zobowiązań produkcyjnych „W dniu stalinowskiej pracy" moźna wymienić inicjatywę załogi odlewni Państwowych Zakładów Mechanicznych w Pasłęku, która wykonała dodatkowo 300 sztuk części zamiennych do maszyn włókienniczych. Z kolei w pasłęckich Zakładach Wyrobów Drzewnych uchwalono przeprowadzenie zbiórki złomu znajdującego się na placu fabrycznym. Ponadto meldowano o załadowaniu dodatkowych wagonów z tarcicą i meblami, a także podkreślono, iż „we własnym zakresie wybielono izbę, w której ustawiona była szlifierka"49. Natomiast zespół woźniców kaflarni w Bartoszycach zamiast przewidywanego tysiąca cegieł - jak informowano - przewiózł 1500 sztuk, a grupa zatrudniona przy suszeniu gliny podwyższyła tego dnia normę wykonania o 25\%. Także uczniowie szkoły koszykarskiej w Rogiedlach wykonali swoje prace na dziesięć dni przed wyznaczonym terminem „ścinając służącą do produkcji koszów pałkę rogożynową na obszarze dwóch hektarów" ${ }^{50}$.

Jak wynika ze sprawozdań, szczególną aktywnością w zaciąganiu „wart stalinowskich” wykazywała się młodzież. Według danych urzędowych, na terenie Olsztyńskiego wzięło w nich udział 215 osób, z których 183 było członkami ZMP ${ }^{51}$. Zobowiązali się oni do przepracowania 1174 roboczogodzin, a następnie składa-

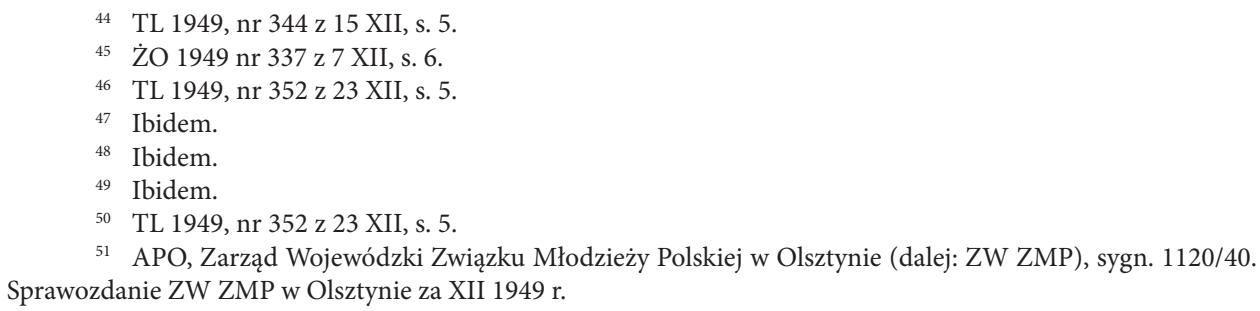


li meldunki o realizacji podjętych zadań. Zetempowcy z Ryńskiego Pola w powiecie giżyckim mieli przeprowadzić remont świetlicy i remont studni szkolnej, a koło ZMP w Galinach podjęło zobowiązanie o wyremontowaniu traktora z miejscowego Państwowego Ośrodka Maszynowego. Z kolei koło ZMP w Małdytach „postanowiło zakupić bibliotekę myślicieli marksizmu-leninizmu”, natomiast zetempowcy reprezentujący koło działające przy Spółdzielni Krawieckiej w Morągu zobowiązywali się do zorganizowania pięciu brygad współzawodnictwa pracy. Ponadto zobowiązywali się oni „pogłębić sojusz robotniczo-chłopski”, zwiększyć produkcję oraz „przepracować dodatkowe roboczogodziny dla Polski Ludowej” 52 . Miano się też „zapoznać z życiorysem tow. Stalina, brać przykład z bohaterskiej młodzieży radzieckiej, podnosić stale poziom produkcji wzmocnić przyjaźń polsko-radziecką oraz pogłębić poziom swój z zakresu marksizmu-leninizmu" ${ }^{53}$. Podkreślano przy tym dużą pomoc i zaangażowanie w całą akcję Komendy Chorągwi ZHP oraz Związku Samopomocy Chłopskiej, które „podjęły szereg zobowiązań i uchwaliły pozdrowienia dla tow. Stalina"54. Podobne działania podjęła również Komenda Wojewódzka Powszechnej Organizacji „Słuźba Polsce”. W grudniu 1949 roku cały terenowy aparat SP (i aktyw junacki) czynnie włączyli się do organizacji obchodów rocznicy urodzin Józefa Stalina. Dekorowano sale świetlicowe, przygotowywano okolicznościowe gazetki ścienne, a młodzież miała obowiązek zapoznania się z życiorysem generalissimusa jednocześnie podkreślając, jego „wielkie zasługi” w „odzyskaniu” przez Polskę niepodległości ${ }^{55}$. Także wiejskie koła ZMP w gminie Gietrzwałd wspólnie z kołami gromadzkimi postanowiły „zapoznać się z życiorysem" Józefa Stalina oraz zorganizować w dwa koła TPPR, natomiast zetempowcy z kół miejskich i gminnych powiatu olsztyńskiego meldowali m.in. o „podniesieniu poziomu ideologiczno-politycznego swoich członków, zwiększeniu prenumeraty prasy, a także o wykonaniu gazetek ściennych" ${ }^{56}$. Podobnie członkowie ZMP z gminy Barczewo zobowiązali się do założenia dwóch nowych kół, wyremontowania świetlicy ZHP oraz „zapoznania się” z życiorysem Stalina, natomiast uczniowie Państwowej Szkoły Pracy Społecznej w Olsztynie dla uczczenia urodzin Stalina postanowili „sporządzić katalog alfabetyczny i działowy dla biblioteki KM PZPR w Olsztynie oraz założyć kartę książek" ${ }^{57}$. Zarząd Grodzki TPPR w Olsztynie ogłosił konkurs na „najlepszy fotomontaż o życiu, walce i działalności

52 Ibidem.

53 Ibidem.

54 Ibidem.

55 Zob. R. Gross, Powszechna Organizacja „Stużba Polsce” w województwie olsztyńskim w latach 1948 1955, Olsztyn 2011, s. 118.

56 ŻO 1949, nr 345 z 15 XII, s. 6

57 TL 1949, nr 347 z 18 XII, s. 5. 
Generalissimusa" ${ }^{38}$. Nie zabrakło też głosu olsztyńskich sportowców oraz działaczy sportowych i pracowników Wojewódzkiego Urzędu Kultury Fizycznej, którzy „zobowiązali się w grudniu [1949 r.] dodatkowo przeszkolić 100 aktywistów i przodowników sportowych". Ponadto pracownicy WUKF w Olsztynie w ciągu niespełna trzech miesięcy postanowili „nauczyć czytać i pisać dziesięciu sportowców analfabetów”. Na specjalnych zebraniach zobowiązano się „zapoznać wszystkich

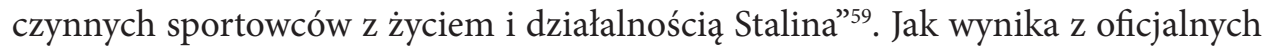
danych, w związku z zaplanowanymi uroczystościami, w Olsztyńskiem ogółem podjęto 350 zobowiązań o szacunkowej wartości ponad 3300 tys. zł. ${ }^{60}$

Przewodniczący olsztyńskiej MRN Aleksander Kruczyński podkreślał także, iż „pożądane jest”, by w całej akcji zobowiązania składały nie tylko zakłady produkcyjne, ale również starostwa powiatowe, oraz instytucje samorządowe i organizacje społeczne, w kierunku usunięcia biurokracji, socjalistycznego podejścia do żywego człowieka, podniesienie stylu pracy tych instytucji itp." ${ }^{\text {. }}$. W ślad za tym zaczęły więc napływać kolejne zobowiązania. Zazwyczajich treść stanowiły meldunki o usprawnieniu organizacji szpitali, domów dziecka czy zakładów opiekuńczych, a także podniesienie poziomu ideologicznego personelu tych placówek. I tak pracownicy Szpitala Wojewódzkiego w Olsztynie meldowali, iż „dla 70-lecia Wielkiego Wodza Proletariatu Swiatowego” zradiofonizowali szpital, a także doprowadzili „do stanu użyteczności” materace i siatki w szpitalnych łóżkach. Poza tym „zrobiono i przesypano" 230 poduszek do nowych poszew ${ }^{62}$. Podobnie pracownicy Domu Małego Dziecka w Mrągowie zobowiązali się „własnymi siłami” wykonać „przeróbkę materaców dla dzieci oraz zainstalować wanienki w zakładzie" ${ }^{63}$. Podkreślano również, że na uwagę zasługuje uchwała koła Związków Zawodowych Pracowników Służby Zdrowia braniewskiego szpitala, gdzie postanowiono „oddać chorym do użytku 4 nowe sale”. Pracownicy szpitala w Lidzbarku Warmińskim zobowiązali się wykonać „we własnym zakresie” reparację bielizny szpitalnej ${ }^{64}$. Z oczywistych względów duże znaczenie propagandowe nadano sprawie przyspieszenia remontu gmachu TPPR w Olsztynie przy ul. Szrajbera. Ponieważ początkowo termin zakończenia robót był zagrożony, postanowiono pracować także wieczorami, co pozwoliło oddać budynek do użytku w przeddzień 70. rocznicy urodzin „Wodza klasy robotniczej”65.

58 ŻO 1949, nr 340 z 10 XII, s. 6.

59 ŻO 1949, nr 348 z 18 XII, s. 6.

60 APO, ZW ZMP, sygn. 1120/40. Sprawozdanie ZW ZMP w Olsztynie za XII 1949 r.

${ }_{61}$ APO, PMRN, sygn. 458/1. Pismo przewodniczącego MRN w Olsztynie Aleksandra Kruczyńskiego do Okręgowej Rady Związków Zawodowych z 10 XII 1949 r.

${ }_{62}$ APO, PMRN, sygn. 458/1. Protokół nr 15/49 posiedzenia plenarnego MRN w Olsztynie z 19 XII 1949 r.; TL 1949, nr 345 z 16 XII, s. 7.

63 Ibidem.

64 Ibidem.

65 ŻO 1949, nr 348 z 18 XII, s. 6. 
Dla podniesienia poziomu ideologicznego pracowników koła związkowe służby zdrowia w szpitalach powiatowych w Morągu, Nidzicy i Giżycku postanowiły zorganizować kursy języka rosyjskiego. Z kolei koło związkowe w sanatorium ZUS w Olsztynku podjęło się zorganizowania 100 tomowej biblioteki zakładowej, zaś koło w Nidzicy otwarcia w szpitalnej świetlicy kącika „pism radzieckich”. Związkowcy zobowiązali się także utworzyć we wszystkich szpitalach województwa olsztyńskiego grupy samokształceniowe, w których miano studiować życiorys Stalina tak, by wszyscy członkowie do 22 stycznia 1950 roku, tj. do piątej rocznicy „wyzwolenia Olsztyna przez Armię Radziecką zapoznali się z życiorysem i działalnością Wielkiego Wodza mas pracujących"66. Z kolei pracownicy zbiornicy jaj w Ostródzie postanowili utworzyć bibliotekę, składającą się z „dzieł” dotyczących życia i działalności, bądź też napisanych przez samego Stalina ${ }^{67}$.

Odnotowano również przypadki współpracy między poszczególnymi miastami. I tak Zarząd Wojewódzki Związku Samopomocy Chłopskiej w Olsztynie, razem z organizacją wojewódzką ZSCh z Białegostoku zobowiązał się do otwarcia 45 nowych świetlic gromadzkich ${ }^{68}$. Informowano przy tym, że w obu województwach powstanie 5 nowych kół gospodyń wiejskich, natomiast w dniu urodzin generalissimusa, przypadających 21 grudnia 1949 roku, zaplanowano wygłoszenie pogadanek na temat, „zycia i czynów towarzysza Stalina”. Planowano także zebranie 200 tys. zł na budowę „Pomnika Wdzięczności dla Armii Radzieckiej” w obu miastach ${ }^{69}$.

Aby wykonanie wszystkich zobowiązań przebiegało bez zakłóceń minister bezpieczeństwa publicznego 14 grudnia 1949 roku skierował pismo do szefów wojewódzkich urzędów bezpieczeństwa publicznego i komendantów wojewódzkich MO w sprawie „wzmożenia walki z wrogą propagandą antyrządową i antyradziecką w okresie obchodów 70. rocznicy urodzin generalissimusa"70. Ślady działań WUBP w Olsztynie odnajdujemy w jednym z meldunków, w którym informowano, że podczas wykonywania zadania produkcyjnego podjętego przez załogę Zakładu Przemysłu Drzewnego w Szczytnie dla uczczenia urodzin Józefa Stalina, „zaistniał fakt wykręcenia śrub w maszynie, jednak na skutek szybkiej orientacji obsługujących, maszyna nie została uszkodzona"71. Jednak podobnych przypadków nie

66 ŻO 1949, nr 346 z 16 XII, s. 6.

67 Ibidem.

68 Ibidem.

69 TL 1949, nr 347 z 18 XII, s. 5. Warto dodać, że zarówno w Białymstoku (7 listopada 1951 r.), jak i w Olsztynie (21 lutego 1954 r.) ostatecznie doszło do odsłonięcia pomników. Jednak w 1990 r. białostocki Pomnik Wdzięczności Armii Radzieckiej został rozebrany, natomiast olsztyński, potocznie określany „szubienicami”, nadal stoi w centrum miasta. Zob. Katalog białostockich pomników, tablic pamiątkowych i miejsc pamięci narodowej, Białystok 2015, ss. 55-56.

70 A. Kochański, Polska 1944-1991. Informator historyczny, T. I: Podział administracyjny. Ważniejsze akty prawne, decyzje i enuncjacje państwowe (1944-1956), Warszawa 1996, s. 303.

71 Archiwum Instytutu Pamięci Narodowej. Oddział w Białymstoku (dalej: AIPN Bi), sygn. 084/5, k. 238-241. Sprawozdanie szefa WUBP w Olsztynie płk Antoniego Pundy z 1 I 1950 r. 
było zbyt wiele.

W czasie obchodów 70. rocznicy urodzin sowieckiego dyktatora - zgodnie ze wspomnianą już instrukcją KC PZPR - prowadzono kampanię pisania listów, pocztówek i laurek do Stalina „pełnych wdzięczności i przywiązania”. Podkreślano przy tym, że napływały one „od chłopów i od poetów, od inteligentów i od górników, od matek i od młodzieży, od fornali i od nauczycieli’”2. Miało to świadczyć o rzekomej powszechności i spontaniczności całej akcji, choć treść tych życzeń jeszcze przed wysłaniem była dokładnie kontrolowana. Według oficjalnych danych z całego kraju wysłano 563340 listów, pocztówek i laurek adresowanych do Stalina z czego najmniej, bo jedynie 8814 , czyli 1,56 proc. z województwa olsztyńskiego ${ }^{73}$. Jednak nie wszystkie listy były kierowane bezpośrednio do „największego przyjaciela Polski”. Na przykład uczniowie Państwowego Liceum Ogólnokształcącego dla Dorosłych w Olsztynie „wystosowali do młodzieży jednej ze szkół w bohaterskim Stalingradzie list z serdecznymi pozdrowieniami i wyrazami podziwu i uznania”. W liście tym olsztyńscy uczniowie deklarowáli,że będą „zawsze dążyli do zacieśnienia więzów przyjaźni”, łączących oba „bratnie narody” oraz z całych sił będą „walczyć o trwały pokój na świecie, z obozem imperiališstów i podźegaczy wojennych, którzy chcą rozpętać nową wojnę”, co miało świadczyć „o żywym uczuciu wdzięczności dla wielkiego przyjaciela młodzieży całego świata Józefa Stalina"74.

Widomym przejawem „serdecznych uczuć" całego społeczeństwa miała być rzekomo samorzutnie podjęta akcja składania darów i upominków, wykonanych zarówno indywidualnie, jak i zbiorowo „dla Wodza klasy robotniczej”75. Wśród darów przekazanych z Olsztyńskiego „oryginalnym i wysoce artystycznym” wykonaniem zwróciła uwagę "płaskorzeźba w drzewie w formie ryngrafu” przedstawiająca Stalina "po zwycięstwie nad faszyzmem na tle sztandarów Związku Radzieckiego oraz nad zdruzgotaną swastyką" przekazana przez Państwowe Zakłady Mechaniczne i Odlewnię w Pasłęku ${ }^{76}$. Podkreślano, że na „szczególne wyróżnienie" zasłużył duży portret olejny Stalina pędzla Andrzeja Samulowskiego „malarza samouka Polaka miejscowego pochodzenia”, który w podarunku przygotowała młodzież z Wiejskiego Ogniska Muzycznego w Gietrzwałdzie. Portret generalissimusa oprawiony był $\mathrm{w}$ „ramy $\mathrm{z}$ inkrustacjami przedstawiającymi fragmenty Olsztyna, chorągwie Związku Radzieckiego i Polski oraz liście laurowe"77. Z kolei Olsztyńskie Zakłady Wyrobów Drzewnych nr 10 ofiarowały „plakietę-płaskorzeźbę" w drewnie przedstawiającą gołębia pokoju. Olsztyńskie Zakłady Ceramiki

72 Cyt. za: O Józefie Stalinie. Na 70-lecie narodzin, Warszawa 1949, ss. 28-29.

73 Zob. R. Kupiecki, op. cit., s. 95.

74 ŻO 1949, nr 340 z 10 XII, s. 6.

75 ŻO 1949, nr 345 z 15 XII, s. 6.

76 TL 1949, nr 343 z 14 XII, s. 5; ŻO 1949, nr 345 z 15 XII, s. 6.

77 Ibidem. 
Czerwonej przygotowały „piękny album w skórzanej oprawie” zawierający fotografie, które przedstawiały „rozwój, pracę i życie Zakładów”. Do przekazanego daru załączono list od załogi - jak nie bez dumy podkreślano - napisany w języku rosyjskim. Album ofiarowali także pracownicy Olsztyńskich Zakładów Graficznych, a zamieszczone w nim zdjęcia, według ofiarodawców, miały „niewątpliwie wartość dokumentu historycznego”, gdyż obrazowały „szybki rozwój i rozbudowę Zakładów, którą umożliwiła pomoc techniczna Związku Radzieckiego" ${ }^{\text {"78 }}$. Wśród innych upominków zwracał uwagę "nowy model naprężacza semaforowego" wykonany przez załogę warsztatów elektrotechnicznych DOKP w Olsztynie, miniatura ciągnika „Ursus” z pługiem, ofiarowana przez robotników warsztatów Technicznej Obsługi Rolnictwa w Olsztynie oraz model młockarni wykonany przez załogę Warmińskiej Fabryki Młocarń w Dobrym Mieście. Nie zabrakło też upominków od młodzieży. Na przykład uczeń stolarski, piętnastoletni Norbert Skok z Olsztyna, pracując w stolarni Spółdzielni Budownictwa Wiejskiego, wykonał model zagrody wiejskiej ${ }^{79}$. Poza tym uwagę przykuwała także „pięknie haftowana poduszka z herbem ZSRR", będąca darem Koła Gospodyń Wiejskich z Tyrowa ${ }^{80}$. Jak informowano, wszystkie dary świata pracy Warmii i Mazur zostały zgromadzone w Komitecie Wojewódzkim PZPR w Olsztynie, skąd następnie przewieziono je do Warszawy, gdzie 13 grudnia 1949 roku w salach Muzeum Narodowego otwarto wystawę wszystkich upominków napływających z całej Polski ${ }^{81}$. Trzy dni później z Warszawy do Moskwy wyruszył specjalny pociąg wiozący „dary społeczeństwa polskiego dla Towarzysza Stalina"s2.

Jedną z bardziej spektakularnych form uczestnictwa młodzieży w grudniowych uroczystościach była zorganizowana z inicjatywy ZMP „gwiaździsta sztafeta”, która stała się częścią ogólnopolskiej akcji o tej samej nazwie ${ }^{83}$. Polegała ona na tym, że informacje o podjętych zobowiązaniach lub przekroczeniu norm pracy, a także "pozdrowienia młodzieżowe dla tow. Stalina” były przekazywane przez przedstawicieli szkół i fabryk na wiecach powiatowych, skąd sztafety na piechotę, rowerami, motocyklami bądź samochodami kierowały się na wiec w Olsztynie, na którym wybierano delegację wojewódzką mającą się udać do Warszawy ${ }^{84}$. Przygotowania do tej akcji rozpoczęto 7 grudnia 1949 roku, kiedy powołano wojewódzki komitet

78 ŻO 1949, nr 345 z 15 XII, s. 6.

79 TL 1949, nr 343 z 14 XII, s. 5.

80 ŻO 1949, nr 345 z 15 XII, s. 6

81 TL 1949, nr 344 z 15 XII, s. 5; ŻO 1949, nr 345 z 15 XII, s. 6.

82 TL 1949, nr 347 z 18 XII, s. 5.

83 Szerzej: B. Tracz, Przejawy publicznego kultu Józefa Stalina na Górnym Ślasku w latach 1945-1956, Szkice Archiwalno-Historyczne, 2014, nr 11, s. 184.

${ }^{84}$ APO, KW PZPR, 1141/1988. Sprawozdanie z przebiegu obchodów 70-lecia urodzin Józefa Stalina; por. P. Osęka, Rytuały stalinizmu. Oficjalne święta i uroczystości rocznicowe w Polsce 1944-1956, Warszawa 2007, ss. 162-163. 
sztafety, a także przeprowadzono odprawę przewodniczących zarządów powiatowych. Zgodnie z zaleceniami Zarządu Głównego ZMP „cały ciężar” akcji skierowano „na gromady, gminy i PGR-ry, gdzie - jak podkreślano - „Z całą świadomością i dosyć mocno postawiliśmy imię Stalina, genialnego wodza proletariatu całego świata”, co młodzież miała przyjąć z „entuzjazmem” i wykazać przy tym „wielkie przywiązanie do tow. Stalina wielkiego przyjaciela narodu polskiego" ${ }^{\text {"5. }}$. Ponadto Zarząd Wojewódzki ZMP skierował do pomocy w poszczególnych powiatach ok. 500 młodych aktywistów. Jednak jak wynika z meldunków także i w tym przypadku nie obyło się bez kłopotów. W sprawozdaniu ZMP z grudnia 1949 roku podkreślano, iż poza „dominującymi dobrymi momentami” podczas sztafety występowały „trudności ze strony reakcyjnej części ludności, która starała się wszelkimi sposobami przeszkodzić Związkowi Młodzieży Polskiej w tej akcji”. Miały o tym świadczyć takie fakty, jak „pobicie koleżanki, która wiozła meldunki z gromady Pogorzel Wielka do gminy Drygały, pow. Pisz"86. Jednak wydaje się, że mimo wszystko były to przypadki incydentalne, a sama inicjatywa szzczególnie wśród zetempowców cieszyła się sporym zainteresowaniem.

W godzinach wieczornych 14 grudnia 1949 roku sztafety powiatowe dotarly do Olsztyna, gdzie na placu gen. Świerczewskiego odbył się wiec, którego liczbę uczestników szacowano na około 8 tys. osób ${ }^{87}$. Kulminacyjnym punktem wiecu miał być przyjazd młodzieżowej sztafety motocyklowej wiozącej meldunki ze wszystkich powiatów województwa olsztyńskiego. Oto jak w lokalnej prasie relacjonowano ten moment: „wśród tłumów, zalegających iluminowany pochodniami plac, nastrój oczekiwania rośnie. Wreszcie pada okrzyk - już jadą! Na plac gen. Świerczewskiego wpada sztafeta. Grupa motocyklistów z czerwonymi szarfami na piersiach, na których widnieją nazwy powiatów, kolejno składa meldunki, przyjmowane przez przedstawiciela Partii i przewodniczącego ZW ZMP"s8. Jeszcze tego samego dnia do Warszawy wyjechała dziesięcioosobowa sztafeta wojewódzka, na czele z przewodniczącym Zarządu Miejskiego ZMP Leszkiem Mikołajczykiem, która w stolicy miała złożyć meldunki o zobowiązaniach podjętych przez olsztyńską młodzież ${ }^{89}$. W tekście meldunku czytamy m.in. „Drogi Tow. Stalinie! My, młodzież ziemi warmińsko-mazurskiej zachowamy na zawsze pamięć o pomocy, której udzielał nam i udziela Związek Radziecki. Zachowamy na zawsze wdzięczność do Kraju Rad i do jego Wodza Wielkiego Stalina, dzięki któremu mieliśmy możność powrócić na nasze prastare ziemie polskie Warmii i Mazur. My młodzież ziemi

85 APO, ZW ZMP, sygn. 1120/40. Sprawozdanie ZW ZMP w Olsztynie za XII 1949 r.

86 Ibidem.

${ }^{87}$ APO, KW PZPR, sygn. 1141/1221.Komunikat KW PZPR w Olsztynie z 16 XII 1949 r.

88 Cyt. za: ŻO 1949, nr 346 z 16 XII, s. 6.

89 APO, KW PZPR, sygn. 1141/1221. Komunikat KW PZPR w Olsztynie z 16 XII 1949 r.; TL 1949, nr 347 z 17 XII, s. 5. 
warmińsko-mazurskiej wzmożemy wysiłki w budownictwie socjalizmu w kraju, a tym samym przyczynimy się do wzrostu sił pokoju i postępu, dzieła któremu poświęciłeś całe życie" ${ }^{\prime 90}$. Jak informowano, w poszczególnych etapach młodzieżowej sztafety w województwie olsztyńskim ogółem wzięło udział 2811 osób, a wartość przyjętych zobowiązań zawartą w meldunkach oceniano na 19930 tys. zł. ${ }^{91}$

Obchodom siedemdziesiątej rocznicy urodzin Stalina towarzyszyło również organizowanie okolicznościowych masówek i wieców ${ }^{92}$. Wraz ze zbliżaniem się oficjalnej daty urodzin sowieckiego dyktatora, ich liczba była coraz większa. W dniach 17 i 18 grudnia 1949 roku w miastach powiatowych województwa olsztyńskiego odbyły się wiece z udziałem posłów na Sejm Ustawodawczy RP. Spotkania, w których liczbę uczestników szacowano na 4750 osób, zostały „obsłużone” m.in. przez posłów PZPR reprezentujących Warmię i Mazury - Wacława Gumińskiego i Kazimierę Świętochowską. Omówiono „aktualne zagadnienia polityczne, szczególnie podkreślając

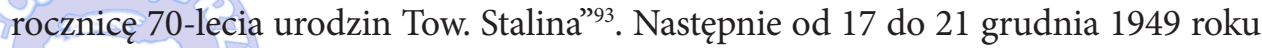
w powiatach odbyły się odczyty i rocznicowe akademie, podezas których prelekcje wygłosili przedstawiciele KC i KW PZPR ${ }^{94}$. Jak wynika z dokumentów tylko 18 grudnia 1949 roku w 125 ,punktach gminnych i zespołach PGR” województwa olsztyń skiego odbyły się uroczyste akademie, w których miało uczestniczyć 30541 osób ${ }^{95}$. W ciągu następnych dwóch dni, a mianowicie 20 i 21 grudnia 1949 roku podobne uroczystości zanotowano w dziewięciu powiatach województwa, a liczbę uczestników szacowano na 15300 osób ${ }^{96}$. W celu uatrakcyjnienia spotkań, po zakończeniu oficjalnej części akademii z reguły organizowano występy artystyczne z udziałem miejscowych zespołów folklorystycznych oraz zabawy ludowe ${ }^{97}$. Ogółem na terenie województwa olsztyńskiego przeprowadzono 143 wiece oraz 1030 masówek, w których liczbę uczestników szacowano na ponad 90 tys. osób ${ }^{98}$. Szczególną aktywnością na tym polu wykazywała się wojewódzka organizacja ZMP licząca wówczas 33177 członków zorganizowanych w 1565 kołach ${ }^{99}$. Jednak, jak wynika z meldunków, nie wszędzie atmosfera była aż tak entuzjastyczna. Np. w gminie Kożuchy na terenie po-

90 Cyt. za: ŻO 1949, nr 346 z 16 XII, s. 6.

91 APO, KW PZPR, sygn. 1141/1221. Zestawienie masówek i wieców z okazji uczczenia 70-lecia urodzin Stalina z 15 XII 1949 r.; ibidem, Komunikat KW PZPR w Olsztynie z 21 XII 1949 r.

92 APO, ZW ZMP, sygn. 1120/40. Sprawozdanie ZW ZMP w Olsztynie za XII 1949 r.

93 APO, KW PZPR, sygn. 1141/1221. Komunikat KW PZPR w Olsztynie z 21 XII 1949 r.

94 Ibidem.

95 Ibidem.

96 Ibidem.

97 Ibidem.

98 APO, ZW ZMP, sygn. 1120/40. Sprawozdanie ZW ZMP w Olsztynie za XII 1949 r.; por. ibidem, KW PZPR, sygn. 1141/1221. Zestawienie masówek i wieców z okazji uczczenia 70-lecia urodzin Józefa Stalina z 15 XII $1949 \mathrm{r}$.

99 APO, ZW ZMP, sygn. 1120/40. Sprawozdanie ZW ZMP w Olsztynie za XII 1949 r.; TL 1949, nr 332 z 3 XII, s. 5. 
wiatu piskiego, podczas masówki miejscowy sołtys stwierdził, że „on nie podpisze pozdrowienia [dla Stalina - W.G.], ani nikt z obecnych". W efekcie tego swoje podpisy złożyło jedynie 5 osób, natomiast 52 wyszły z zebrania. Podobnie rzecz się miała w gminie Waplewo w powiecie ostródzkim gdzie, jak wynika ze sprawozdania, „nie można było zorganizować ani jednej masówki, ani wiecu [...] z powodu wrogo nastawionej miejscowej ludności”"100.

W miarę, jak zbliżał się dzień 70. urodzin Stalina, obserwować można było kulminację działań, mających uświetnić to wydarzenie. Od 17 do 21 grudnia 1949 roku w większych zakładach przemysłowych oraz instytucjach odbywały się okolicznościowe akademie, zazwyczaj składające się z części oficjalnej, gdzie wygłaszano referaty o życiu i działalności sowieckiego dyktatora, a także z części artystycznej, na ogół składających się z wiązanki pieśni i deklamacji wierszy sławiących Stalina i Związek Sowiecki ${ }^{101}$. W poniedziałek, 19 grudnia 1949 roku, odbyło się plenarne posiedzenie Miejskiej Rady Narodowej w Olsztynie, któremu nadano szczególnie uroczysty charakter, wprowadzając do porządku dziennego „kilka nadzwyczajnych punktow" ${ }^{102}$. Pierwszym z nich był referat wygłoszony przez przewodniczącego-MRN Aleksandra Kruczyńskiego, który omówił życie i działálność Józefa Stalina. Następnie, w imieniu poszczególnych klubów radnych, składano deklaracje nawiązujące do zbliżającej się daty urodzin generalissimusa, po czym delegacje zakładów pracy składały meldunki o wykonaniu zobowiązań produkcyjnych, podjętych na cześć Stalina. Potwierdzono wykonanie zobowiązań podjętych przez załogi przedsiębiorstw komunalnych na przykład załoga Miejskich Zakładów Komunikacyjnych uporządkowała pętle trolejbusowe na Osiedlu Mazurskim i w Kortowie, a także posprzątała dwie zajezdnie. Z kolei robotnicy z olsztyńskiej gazowni otworzyli bibliotekę przyzakładową, a pracownicy tartaku przeznaczyli zarobki uzyskane z godzin nadliczbowych na budowę mającego powstać Pomnika Wdzięczności dla Armii Czerwonej w Warszawie. Poza tym pracownicy wszystkich przedsiębiorstw miejskich postanowili „wzmóc współzawodnictwo i podnieść wydajność pracy przez przestudiowanie życiorysu Generalissimusa Stalina"103. Tego samego dnia w świetlicy Okręgowej Rady Związków Zawodowych mieszczącej się w gmachu olsztyńskiego teatru, otwarto wystawę obrazującą „życie, działalność i walkę Wielkiego Wodza międzynarodowego proletariatu"104.

Meldunki o wykonaniu zobowiązań produkcyjnych napływały dosłownie do ostatniej chwili. W środę 21 grudnia 1949 roku o godz. 20.00 pracownicy spół-

\footnotetext{
${ }^{100}$ APO, ZW ZMP, sygn. 1120/40. Sprawozdanie ZW ZMP w Olsztynie za XII 1949 r.

101 APO, KW PZPR, 1141/1988. Sprawozdanie z przebiegu obchodów 70-lecia urodzin tow. Józefa Stalina.

102 ŻO 1949, nr 351 z 21 XII, s. 8.

103 Ibidem.

104 ŻO 1949, nr 349 z 19 XII, s. 6.
} 
dzielni budowlanej „Warmia” zakończyli budowę obiektu przy ul. Działdowskiej ${ }^{105}$, a trzy godziny później załoga spółdzielni „Technik” przekazała do użytku magazyn przy ul. Artyleryjskiej w Olsztynie. Oba budynki popularnie nazywano w mieście „szybkościowcami” ze względu na fakt, iż ich budowa trwała zaledwie osiemnaście dni ${ }^{106}$. W tym samym czasie, $\mathrm{z}$ dwumiesięcznym wyprzedzeniem, otwarto świetlicę dla pracowników Starostwa Powiatowego w Olsztynie. 20 grudnia 1949 roku do dyrekcji przedsiębiorstwa państwowego „Zjednoczenie Energetyczne Okręgu Mazurskiego" napłynęły meldunki o pełnym wykonaniu zobowiązań związanych z uczczeniem 70. rocznicy urodzin Stalina. Jak informowano, wszystkie podokręgi ZEOM-u, czyli olsztyński, kętrzyński i elbląski, nie tylko wykonały wcześniej podjęte zobowiązania, ale je przekroczyły przeprowadzając elektryfikację 40 wsi na Warmii i Mazurach ${ }^{107}$. Z kolei staraniem olsztyńskich pocztowców przygotowano 350 paczek ze słodyczami przeznaczonych dla dzieci z pięciu „podopiecznych wsi” tj. Kaborno, Bruchwałd, Trękus, Skajboty i Patryki. Jak podkreślano każde dziecko miało otrzymać po $600 \mathrm{gr}$. słodyczy, natomiast sieroty po $1000 \mathrm{gr}$. Te „słodkie paczki" miały zostać wręczone wiejskiej dziatwie podczas uroczystości 21 grudnia 1949 rokü

Kulminacja jubileuszowych uroczystości przypadła na środę 21 grudnia 1949 roku. W całym kraju wychodzące tego dnia gazety ukazały się w odświętnej szacie. Wzorem „Trybuny Ludu”, także do regionalnego „Życia Olsztyńskiego” dołączono ośmiostronicową wkładkę zatytułowaną "Stalin - organizator zwycięstwa nad faszyzmem”. Z kolei nad winietą pisma górował czerwony napis „Na 70-lecie urodzin Józefa Stalina" ${ }^{109}$. Także ulice miast przybrały odświętny wygląd. Nie brakowało okolicznościowych haseł, transparentów, flag, a także portretów generalissimusa. Tego dnia jubileuszowe uroczystości organizowały również poszczególne ugrupowania polityczne. Zazwyczaj scenariusz tych imprez był bardzo podobny. Ich żelaznym punktem były referaty o życiu i działalności Stalina, przyjęcie przez zebranych uchwały, a następnie odśpiewanie Międzynarodówki, po czym rozpoczynały się występy artystyczne.

W samym Olsztynie głównym punktem uroczystości związanych z siedemdziesiątą rocznicą urodzin Stalina była akademia zorganizowana przez Komitet Miejski PZPR, która 21 grudnia 1949 roku w godzinach popołudniowych odbyła się w sali państwowego Teatru im. Stefana Jaracza w Olsztynie ${ }^{110}$. Według oficjalnych danych w akademii miało wziąć udział około tysiąca osób, co choćby ze względu na

\footnotetext{
105 Obecnie ul. Radiowa.

106 ŻO 1949, nr 354 z 24-26 XII, s. 8.

107 ŻO 1949, nr 353 z 23 XII, s. 6; ibidem, nr 355 z 27 XII, s. 6.

108 ŻO 1949, nr 350 z 20 XII, s. 4.

109 ŻO 1949, nr 351 z 21 XII, s. 8.

${ }^{110}$ Ibidem.
} 
liczbę miejsc w olsztyńskim teatrze wydaje się liczbą nieco przesadzoną. Na scenie udekorowanej flagami i transparentami, pośrodku której umieszczono olbrzymi portret Stalina oraz sztandary partyjne i związkowe, zasiadło prezydium akademii. Po odegraniu hymnów sowieckiego i polskiego zabrał głos I sekretarz KW PZPR Paweł Wojas. Wygłosił okolicznościowy referat poświęcony „życiu i działalności Józefa Stalina, Budowniczego i Twórcy nowej epoki, Przodownika wszystkich narodów miłujących wolność i pokój”"11. Mówca szczególnie uwypuklił rolę Stalina jako „kontynuatora nauki marksizmu-leninizmu i genialnego Wodza Rewolucji, która obaliła władzę wyzyskiwaczy, stwarzając fundamenty pod budowę nowego świata" ${ }^{112}$. Jak podkreślano, referat „był kilkakrotnie przerywany burzliwymi i żywiołowymi oklaskami i skandowanymi okrzykami na cześć Wielkiego Stalina"113. Kończąc swoje wystąpienie I sekretarz KW PZPR złożył „Generalissimusowi Stalinowi w imieniu mas pracujących województwa olsztyńskiego serdeczne życzenia wielu lat życia i pracy dla dobra i szczęścia całej ludzkości”"114. Następnie odczytano uroczysty adres, który - jak podkreślano - zóstał przyjęty „entuzjastycznie” przez zebranych ${ }^{115}$. W trakcie odczytywania treści adresu, kiedy padły słowa: „Uzbrojeni w naukę Lenina i Stalina wzbogaceni doświadczeniami Narodów Radzieckich, wykonamy 6-letni plan budowy fundamentów Socjalizmu, tak jak wykonaliśmy zwycięski trzyletni plan odbudowy", ponownie wybuchły burzliwe oklaski i skandowania na cześć „Wielkiego Stalina” ${ }^{116}$. Po zakończeniu części oficjalnej nastąpiła część artystyczna, którą prowadził aktor olsztyńskiego teatru Stanisław Igar. Zaprezentowano „Dumkę Kozacką o Stalinie” wykonaną przez chór złożony z uczniów sześciu olsztyńskich szkół z towarzyszeniem orkiestry symfonicznej pod batutą Stanisława Truszczyńskiego. Następnie orkiestra wykonała „Kantatę o Stalinie” w kompozycji Aleksandra W. Aleksandrowa. Nie zabrakło także innych pieśni oraz recytacji wierszy. Akademię zakończyła „Pieśń o Stalinie” w wykonaniu połączonych chórów olsztyńskich szkół.

Także Wojewódzki Komitet Wykonawczy ZSL razem ze spółdzielnią wydawniczą "Zagon” zorganizował akademię dla uczczenia 70. rocznicy urodzin Stalina ${ }^{117}$. Podobna impreza odbyła się również w lokalu Stronnictwa Demokratycznego w Olsztynie. Podczas akademii uchwalono rezolucję, w której przesłano Stalinowi „wyrazy hołdu i czci w uznaniu Jego ogromnych zasług w walce o wyzwolenie klasy robotniczej i utrwalenie światowego pokoju”. W dalszej części rezo-

\footnotetext{
111 ŻO 1949, nr 353 z 23 XII, s. 6.

112 Ibidem.

113 ŻO 1949, nr 353 z 23 XII, s. 6.

114 Ibidem.

115 Ibidem.

116 Ibidem.

117 ŻO 1949, nr 352 z 22 XII, s. 4.
} 
lucji zebrani postanowili „pracą na wszystkich odcinkach życia przyczynić się do pełnego zrealizowania planu 6-letniego, prowadzącego masy Polski Ludowej do socjalizmu"118. Okolicznościową akademię w dniu 22 grudnia 1949 roku zorganizowało też olsztyńskie Stronnictwo Pracy ${ }^{119}$. Również koła TPPR, ZMP i Związku Zawodowego Pracowników Państwowych przy Urzędzie Wojewódzkim w Olsztynie 20 grudnia 1949 roku zorganizowały obchody 70. rocznicy urodzin Stalina ${ }^{120}$.

Należy też odnotować, że w olsztyńskiej świetlicy międzyzakładowej ORZZ otwarto wystawę, przygotowaną wspólnie z TPPR, poświęconą życiu i działalności „wielkiego Wodza międzynarodowego proletariatu” ${ }^{121}$. Nad ekspozycją, którą podzielono na poszczególne działy tematyczne, górował wielki napis: „Józef Stalin - wódz naszej epoki”. Warto też dodać, że środkową część sali wypełniały plansze $\mathrm{z}$ fotografiami ilustrującymi życie i pracę $\mathrm{w}$ poszczególnych republikach sowieckich, rozwój nauki i techniki oraz działalność pionierów ${ }^{122}$. Nie zabrakło także stoisk z czasopismami radzieckimi oraz najnowszymi tłumaczeniami polskimi dzieł "wielkiego Wodza i Nauczyciela" ${ }^{123}$. Uroczystóści te w zasadzie zakończyły olsztyńskie obchody związane z siedemdziesięcioleciem urodzin Józefa Stalina.

W porównaniu do innych województw, w Olsztyńskiem uroczystości związane z 70. rocznicą urodzin Józefa Stalina, mimo że były realizowane według z góry narzuconego scenariusza, miały znacznie skromniejszy wymiar. Wydaje się, że złożyło się na to co najmniej kilka przyczyn. Po pierwsze, Olsztyńskie było województwem typowo rolniczym, w dodatku jeszcze dość słabo zaludnionym, natomiast większe zakłady przemysłowe w których zazwyczaj podejmowano zobowiązania produkcyjne stanowiły wówczas niewielki procent załóg pracowniczych. I choć oficjalnie głoszono, iż zainteresowanie społeczeństwa tymi uroczystościami było „dosyć duże”, to jednak należy sądzić, że ocena ta była przesadzona, zapewne użyta na potrzeby propagandy. Można również założyć, że większość osób, które zdecydowały się uczestniczyć $\mathrm{w}$ tych uroczystościach czyniły to raczej nie z przekonania, ale bardziej z obawy o możliwe negatywne następstwa wynikające z nieobecności,

\footnotetext{
118 ŻO 1949, nr 350 z 20 XII, s. 4.

119 Ibidem.

120 ŻO 1949, nr 352 z 22 XII, s. 4.

121 Ibidem.

122 Ibidem.
}

123 W 1949 r. w wielotysięcznych nakładach wydano drukiem zarówno Krótki życiorys J.W. Stalina, jak też szereg prac jego autorstwa. Nakładem Wydawnictwa „Książka i Wiedza” ukazały się wówczas m.in.: J.W. Stalin, Dzieła, t. I: 1901-1907, t. 2: 1907-1913, idem, Marksizm a kwestia narodowa. Kwestia narodowa a leninizm, idem, O materializmie dialektycznym i historycznym, idem, Międzynarodowy charakter Rewolucji Październikowej, idem, O Leninie, idem, Do młodzieży, idem, Lenin a kwestia sojuszu ze średniakiem. W odpowiedzi towarzyszom kołchoźnikom. Przemówienie na pierwszym wszechzwiązkowym zjeździe kołchoźników - przodowników pracy; idem, Przemówienie w Pałacu Kremlowskim na uroczystości promowania akademików Armii Czerwonej 4 maja 1935 r. Przemówienie na pierwszej wszechzwiązkowej naradzie stachanowców 17 listopada 1935 r.; idem, O projekcie konstytucji ZSRR. Referat na nadzwyczajnym VIII wszechzwiązkowym zjeździe Rad 25 listopada 1936 r. 
którą można było poczytywać jako wyraz pewnej manifestacji politycznej ${ }^{124}$. Nie bez znaczenia było także to, że w województwie olsztyńskim, leżącym w pewnym oddaleniu od centrum Polski, życie społeczne i polityczne toczyło się nieco wolniej, mniej spektakularnie. Poza tym, znaczna część ludności Warmii i Mazur w ramach tzw. repatriacji w latach 1945-1948 została tu przesiedlona z ziem wschodnich przedwojennej Rzeczypospolitej. Ludzie ci dobrze znali zbrodniczy charakter bolszewizmu i - co w pełni zrozumiałe - znacznie rzadziej i mniej entuzjastycznie angażowali się w uroczystości mające sławić sowieckiego dyktatora.

\author{
Witold Gieszczyński, Feierlichkeiten zum 70. Geburtstag von Josef Stalin im Dezember 1949 (am \\ Beispiel der Wojewodschaft Olsztyn)
}

\title{
Zusammenfassung
}

Nach dem Zweiten Weltkrieg hat der Personenkult um Stalin den Höhepunkt erreicht. Sowohl in der Sowjetunion als auch in den Satellitenstaaten von Moskau wurde er nahezu göttlich verehrt. Aus diesem Anlass wurde ein riesiger Propagandaapparat sowohl in der Sowjetunion selbst als auch in den sog. Satellitenstaaten, darunter auch in Polen, in Bewegung gesetzt. In Polen wurden mit dem Jubiläum des sowjetischen Diktators verbundene Feierlichkeiten lange vor dem Kulminationspunkt am 21. Dezember 1949 begonnen. Ähnlich war es in Olsztyn, wo ein aus 38 Personen bestehendes Wojewodschaftskomitee zum 70. Geburtstagsjubiläum von Josef Stalin ins Leben gerufen wurde. Die ersten Feierlichkeiten fanden bereits einige Wochen vor dem 70. Jahrestag des Geburtstages von Stalin statt. Aus Propagandagründen wurden damals verschiedene Kundgebungen, Versammlungen, Akademien und Massenveranstaltungen organisiert. Die Belegschaften der Arbeitsbetriebe machten Produktionsversprechen. Im Vergleich zu anderen Wojewodschaften hatten die Feierlichkeiten zum 70. Geburtstagsjubiläum von Josef Stalin in der Wojewodschaft Olsztyn ein wesentlich bescheideneres Ausmaß - trotz des von oben auferlegten Szenarios. Die Wojewodschaft Olsztyn war typisch landwirtschaftlich geprägt, dazu war sie noch relativ schwach besiedelt und lag in einer gewissen Entfernung von Zentralpolen.

Übersetzt von Witold Gieszczyński

Witold Gieszczyński, Joseph Stalin's birthday celebrations in December 1949 (the example of the Olsztyn Voivodeship)

Summary

The celebrations related to the $70^{\text {th }}$ anniversary of the birth of Joseph Stalin began well before their culmination, which was to take place on December 21, 1949. The communist authorities issued a special instruction which strictly regulated the course of these celebrations. Special party meetings were organized to celebrate the dictator. Young people gathered in workplaces, schools and youth organizations were also expected to participate in the celebrations. Furthermore, it was recommended to study the biography of Stalin and decorate public buildings with Polish and Soviet colours, as well as portraits of Stalin and related slogans.

In Olsztyn, as in other Polish cities, the Provincial Committee for the celebration of the $70^{\text {th }}$ anniversary of Stalin was established, which included members of the political and administrative authorities, as well as representatives of the army, trade unions, social, scientific, creative and artistic organisations, and industry leaders. However, compared to other regions in the Olsztyn Voivodeship, the celebrations of the jubilee of the birth of Joseph Stalin had a much more modest dimension, mainly due to the typically agricultural character of the region, as well as the relatively small population of Warmia and Masuria at that time.

Translated by Aleksander Pluskowski

${ }^{124}$ APO, KW PZPR, sygn. 1141/1988. Sprawozdanie z przebiegu obchodów 70-lecia urodzin Józefa Stalina. 
dr hab. Witold Gieszczyński

Instytut Historii i Stosunków Międzynarodowych

Uniwersytet Warmińsko-Mazurski w Olsztynie

witold.gieszczynski@uwm.edu.pl

\section{Źródła archiwalne}

Archiwum Instytutu Pamięci Narodowej. Oddział w Białymstoku (AIPN Bi)

- sygn. 084/5, k. 238-241.

Archiwum Państwowe w Olsztynie (APO)

Komitet Wojewódzki Polskiej Zjednoczonej Partii Robotniczej w Olsztynie

- sygn. 1141/1221.

- sygn. 1141/1988.

- sygn. 1141/2713.

Prezydium Miejskiej Rady Narodowej w Olsztynie

- sygn. $458 / 1$.

Zarząd Wojewódzki Związku Młodzieży Polskiej w Olsztynie

- sygn. 1120/40.

Źródla drukowane

Kronika Olsztyna 1945-1950

1972 Kronika Olsztyna 1945-1950 Zapisał i wydał A. Wakar, Olsztyn.

\section{Opracowania}

Borodziej Włodzimierz

1990 Od Poczdamu do Szklarskiej Poręby. Polska w stosunkach międzynarodowych 1945-1947, Londyn.

Duraczyński Eugeniusz

2012 Stalin: twórca i dyktator supermocarstwa, Pułtusk - Warszawa.

Golon Mirosław

2002 Uźródeł „zimnowojennego” podziału świata - powstanie i działalność Biura Informacyjnego Partii Komunistycznych i Robotniczych (Kominformu) w latach 1947-1950, w: Polska w podzielonym świecie po II wojnie światowej (do 1989 r.), red. M. Wojciechowski, Toruń, ss. 91-126.

Gross Radosław

2011 Powszechna Organizacja „Służba Polsce” w województwie olsztyńskim w latach 1948-1955, Olsztyn.

Heller Michał, Niekricz Aleksander

2016 Utopia u władzy. Historia Związku Sowieckiego. Od potęgi do upadku 1939-1991, Poznań.

Iwanow Nikołaj

2017 Komunizm po polsku. Historia komunizacji Polski widziana z Kremla, Kraków.

Jażborowska Inessa

1999 Utworzenie Kominform. Kominform jako narzędzie manipulacji Stalina w Polsce, Dzieje Najnowsze, nr 2, ss. 117-135. 
Józef Stalin. Krótki życiorys

1953 Józef Stalin. Krótki życiorys, oprac. J. Aleksandrow, M. Gałaktionow, W. Krużkow, M. Mitin, W. Moczałow, P. Pospiełow, Warszawa.

Katalog białostockich pomników

2015 Katalog białostockich pomników, tablic pamiątkowych i miejsc pamięci narodowej, Białystok.

Khlevniuk Oleg

2016 Stalin: nowa biografia, Kraków.

Kochański Aleksander

1996 Polska 1944-1991. Informator historyczny, T. I: Podział administracyjny. Ważniejsze akty prawne, decyzje i enuncjacje państwowe (1944-1956), Warszawa.

Kupiecki Robert

1993 „Natchnienie milionów”. Kult Józefa Stalina w Polsce 1944-1956, Warszawa.

Marples David R.

2006 Historia ZSRR. Od rewolucji do rozpadu, Wrocław - Warszawa - Kraków.

Mołdawa Tadeusz

1991 Ludzie władzy 1944-1991. Władze państwowe i polityczne Polski wedlug stanu nă dzień 28 II 1991, Warszawa.

Montefiore Simon Sebag

2015 Stalin: dwór czerwonego cara, Warszawa.

Nalepa Edward Jan

2017 Oddani partii Lenina i Stalina. Czerwonoarmiści w Wojsku Polskim 1943-1968, Piotrków Trybunalski.

O Józefie Stalinie

1949 O Józefie Stalinie. Na 70-lecie narodzin, Warszawa.

Osęka Piotr

2007 Rytualy stalinizmu. Oficjalne święta i uroczystości rocznicowe w Polsce 1944-1956, Warszawa.

Pietrow Nikita

2015 Nowy ład Stalina. Sowietyzacja Europy 1945-1953, Warszawa.

Pipes Richard

2008 Komunizm, Warszawa.

Plamper Jan

2014 Kult Stalina. Studium alchemii władzy, Warszawa.

Radziński Edward

1996 Stalin, Warszawa.

Smaga Józef

1992 Narodziny i upadek imperium. ZSRR 1917-1991, Kraków.

Tracz Bogusław

2014 Przejawy publicznego kultu Józefa Stalina na Górnym Ślasku w latach 1945-1956, Szkice Archiwalno-Historyczne, nr 11, ss. 175-197.

Wieczorkiewicz Paweł Piotr

2017 Sowiety. Historia ZSRS, Łomianki. 
Wielki wódz i nauczyciel Komunistycznej Partii i Narodu Radzieckiego

1949 Wielki wódz i nauczyciel Komunistycznej Partii i Narodu Radzieckiego. Na siedemdziesięciolecie urodzin J.W. Stalina, Wydział Propagandy i Agitacji przy CK WKP(b) oraz Instytut Marksa - Engelsa - Lenina przy CK WKP(b), Warszawa.

Большая Советская Енциклопедия

1976 Большая Советская Енциклопедия, (ред.) А. М. Прохоров, т. 24, Москва.

\section{Prasa}

„Nowe Drogi”. Czasopismo społeczno-polityczne. Organ KC PZPR 1949, nr 5(17), ss. 3-4

„Trybuna Ludu”

- 1949, nr 276 z 8 X, s. 7.

- 1949, nr 292 z 24 X, s.1.

- 1949, nr 305 z 6 XI, s. 5.

- 1949, nr 306 z 7 XI, ss. 1-2.

- 1949, nr 332 z 3 XII, s. 5.

- 1949, nr 343 z 14 XII, s. 5

1949 , nr 344 z 15 XII, s. 5.

- 1949, nr 345 z 16 XII, s. 7.

-1949 , nr 347 z 18 XII, s. 5 .

- 1949, nr 348 z 18 XII, s. 6

„Życie Olsztyńskie”. Pismo Ziemi Warmińsko-Mazurskiej

-1949, , nr 323 z 23 XI, s. 6.

- 1949, nr 337 z 7 XII, s. 6.

- 1949, nr 340 z 10 XII, s. 6.

- 1949, nr 345 z 15 XII, s. 6

- 1949, nr 346 z 16 XII, s. 6

- 1949, nr 347 z 18 XII, s. 5.

- 1949, nr 349 z 19 XII, s. 6.

- 1949, nr 350 z 20 XII, s. 4.

- 1949, nr 351 z 21 XII, s. 8 .

- 1949, nr 352 z 23 XII, s. 5

- 1949, nr 353 z 23 XII, s. 6

- 1949, nr 354 z 24-26 XII, s. 8.

- 1949, nr 355 z 27 XII, s. 6. 